\title{
Evaluation of Environmental Conditions in Two Cities of East Siberia Using Bio-indication Methods (Fluctuating Asymmetry Value and Mutagenic Activity of Soils)
}

\author{
Elena Shadrina ${ }^{1}$, Yakov Vol'pert ${ }^{2}$, Viktoriya Soldatova ${ }^{1}$, Natal'ya Alekseeva ${ }^{1} \&$ Tuyara Pudova ${ }^{2}$ \\ ${ }^{1}$ Institute of Natural Sciences, North-Eastern Federal University, Russia \\ ${ }^{2}$ Research Institute of Applied Ecology of the North, North-Eastern Federal University, Russia \\ Correspondence: Elena Shadrina, North-Eastern Federal University, Belinskogo str., 58, Yakutsk, Russia. Tel: \\ 7-914-225-6989. E-mail: e-shadrina@yandex.ru
}

Received: July 3, 2014 Accepted: July 31, 2014 Online Published: October 14, 2014

doi:10.5539/ijb.v7n1p20 URL: http://dx.doi.org/10.5539/ijb.v7n1p20

\begin{abstract}
Bioindicational evaluation of environmental quality on the territory of Yakutsk and Mirny (East Siberia, Yakutia) has been performed. Fluctuating asymmetry (FA) value of leaves of the Japanese White Birch Betula platyphylla Sukacz. was examined and soil condition was assessed by occurrence of Mitosis Pathologies (MP) in germinating Japanese leek Allium fistulosum L. cultivated on samples of lawn soils. About 18,000 leaves and 37 soil samples (over 20,000 anaphase and telophase cells) was examined. In most samples from city territories statistically significant increase in FA and MP in comparison to unimpaired habitats was registered. Positive correlation between FA value and traffic load as well as total content of heavy metals in soil was found. On the territory of the administrative center (Yakutsk), motor transport was found to be the main source of the pollution. Consequently major streets, especially in the immediate vicinity of roadways, and crossroads with heavy traffic load suffer from pollution most. On the territory of the industrial center (Mirny) pollution spreads from technogenically impaired areas to the residential area. Developmental stability abnormalities and total mutagenic background indicate deterioration of environmental conditions as a consequence of combined impact of negative factors arising from anthropogenically transformed environment.
\end{abstract}

Keywords: fluctuating asymmetry, developmental stability, Betula, environment fitness, mitosis pathologies, total mutagenic background, Allium fistulosum, bioindication, anthropogenic pollution, urbanized territories

\section{Introduction}

Evaluation of environment fitness is a very important task both for planning and carrying out any nature management, nature protection, and environmental safety measures. Technogenic contamination of the environment is multi-component, so even precise data on pollutant levels do not allow one to determine the magnitude of danger they pose to organism. Bioindication methods, as opposed to geochemical methods, provide an idea of cumulative impact of physical and chemical contaminants of natural and anthropogenical origin on organism. Most of these methods are not specific, so they reflect, first of all, the general state of ill-being of an organism irrespective of the underlying factor responsible for its occurrence.

One of promising approaches to characterizing environmental quality is assessment of organism condition by detecting abnormalities of developmental stability, which is characterized by the level of fluctuating asymmetry (FA) of morphological structures (Zakharov, 1987). These insignificant differences between the sides of the body or an organ developing during organogenesis do not have adaptive significance in their own right and do not have noticeable impact on individual viability (Leary \& Allendorf, 1989). Representing a form of phenotypic variability fluctuating asymmetry is determined by both genotype and environmental factors.

The influence of the genotypic factor on developmental stability is variable. In a number of cases an increase in asymmetry level is noted in inbreeding or distant hybridization (Parsons, 1990, 1992; Sherry \& Lord, 1996; Zakharov \& Sikorski, 1997). However, there are studies showing the opposite. A research of natural and laboratory populations of the house mouse (Mus musculus) revealed that hybridization in natural populations often does not affect developmental stability (Alibert, Felclair, Manolakou, Brittondavidian \& Auffray, 1997). Freeman and co-authors (Freeman, Graham, Byrd, McArthur, \& Turner, 1995.) found that in the hybrid zone of 
two sagebrush Artemisia tridentata subspecies most hybrids' developmental stability level was rather high. Consequently, influence of the genotypic constituent on FA level shows only in case of disturbance in general genomic coadaptation (Zakharov, 1987; Zakharov, Zhdanova, Kirik, \& Shkil', 2001).

Environment has significantly greater influence on fluctuating asymmetry values. Increasing destabilization of ontogeny can be observed in animal populations as conditions diverge from optimum zone (Zakharov et al., 2001; Shkil', 2003; Shadrina, 2004, 2005). In plants increase in fluctuating asymmetry level was registered under the influence of such biotic factors as mass proliferation of plant pests, unfavorable forest pathology status (Moller, 1995; Martel, Lempa, \& Haukioja, 1999; Diaz, Pulido, \& Moller, 2004; Gelashvili, Lobanova, Erofeeva, \& Naumova, 2007), as well as change in intensity of abiotic factors: climate change, geographic range periphery, or elevation increase (Zakharov et al., 2001; Wilsey, Haukioja, Koricheva \& Sulkinoja, 1998; Hodar, 2002; Xu, Hu, \& Zhang, 2012; Shadrina \& Vol'pert, 2014).

Thus, the fluctuating asymmetry is among general biological phenomena and can be used as nonspecific stress indicator that reflects strain in interactions between an organism and the environment. Monitoring manifestations of destabilization can provide information not only on increasingly negative biotic or abiotic factors but also on presence of anthropogenic pressure.

In land ecosystems chemical pollution negatively influences plant morphological structures. Heavy contamination can lead to necroses that cause deformation or distortion of lamina (Vainert, Val'ter, Vettsel' et al., 1988). But even when influence is relatively weak and does not lead to necroses, increase in leaf asymmetry was noted in the presence of chemical pollution (Kozlov, Wilsey, Koricheva, \& Haukioja, 1996; Kryazheva, Chistyakova, \& Zakharov, 1996; Zakharov et al., 2000 a; Vasil'ev, Vasil'eva, \& Marin, 2008), in the zone affected by mining industry and exploration surveys (Danilov, Shadrina, \& Vol'pert, 2001; Shadrina, Vol'pert, Danilov, \& Shadrin, 2003; Shadrina, Vol'pert, \& Danilov, 2009; Shadrina, Vol'pert, Alekseeva, Danilov, \& Pudova, 2012; Shadrina, Pudova, \& Soldatova, 2012).

The value of FA in plants is used for evaluation of natural population state as well as evaluation of environmental fitness on the territory of human settlements (Zakharov et al., 2001; Sherzhukova, Krivtsova, Meluzova, \& Mishalenkova, 2002; Soldatova \& Shadrina, 2007; Soldatova, Shadrina, \& Tsopa, 2009; Ibragimova, 2010; Shabalina \& Dem'yanenko, 2011; Savintseva, Egoshina, \& Shiryaev, 2012; Glinyanova \& Bontar, 2013; Youssef, Gurbanov, Haciyeva, Mammedova, \& Khalilov, 2013).

When used for evaluation of the condition of contaminated territories this method can be supplemented by assessment of mutagenicity of contaminated components of natural environment (water, soil). Bioassay provides the possibility to evaluate the total mutagenic background (TMB) of the territory under study (Kurinnyi, 1985).

The goal of our research was to evaluate the environmental state using fluctuating asymmetry parameters and mutagenic background of soils from city territories of varying degrees of anthropogenic pressure.

\section{Method}

The study has been carried out on the territory of two cities - Mirny and Yakutsk. Mirny is situated on the territory of Western Yakutia, its population is about 30,000, it is a center of diamond mining industry, its territory includes residential area and industrial site of Mirny mining and processing works. The city territory is contiguous with waste-rock dumps.

Yakutsk is the administrative center of the Sakha (Yakutia) Republic and is situated in the middle reaches of the Lena River valley. The population is 300,000 . The major sources of air pollution are motor transport, heat power engineering, and construction industry. Primarily due to organic oil burning in motor vehicle engines, significant amount of carbon dioxide and harmful substances (lead; soot; hydrocarbons; and carbon, sulphur, and nitrogen oxides) enters the atmosphere.

We have examined about 16,000 leaves and 37 soil samples from sites with different technogenic load.

\subsection{FA Value Assessment}

For FA value assessment we used a complex of characteristics that was supposed by Zakharov et al. (2000 b) for the silver birch Betula pendula Roth. and tested us for the Japanese White Birch Betula platyphylla Sukacz. (Shadrina et al., 2003). FA was assessed by five characteristics of lamina structure and venation (Figure 1). For each characteristic FA coefficient was calculated as the mean relative difference for the characteristic, which is absolute value of the ratio of the difference to the sum of measurements of the left and right halves of the leaf related to the amount of characteristics (formula 1). The value of the leaf fluctuating asymmetry was assessed by the averaged value of the five measurements. 


$$
F A=A B S\left(\frac{L-R}{L+R}\right)
$$

where: FA, fluctuating asymmetry value; ABS, absolute value; $\mathrm{L}$ and $\mathrm{R}$, measurements of the left and right halves of the leaf.

On the territory of Mirny and in its vicinity 20 sites were examined in two repetitions (in 2003 and 2011). On the territory of Yakutsk 45 sites were examined in two to five repetitions (2001-2005). In each of examined sites we collected 100 leaves (10 leaves from 10 plants). For control group we birch leaves collected from unimpaired habitats of the same region.

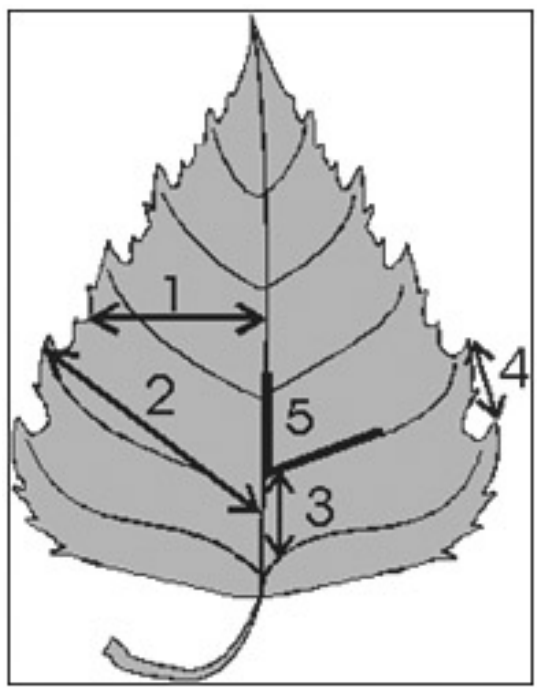

Figure 1. Leaf measurements used for assessment of FA value

1 , width of $1 / 2$ of the leaf;

2, length of the second (starting from the leaf base) second-order vein;

3 , distance between the bases of the first and second second-order veins;

4, distance between the ends of the first and second second-order veins;

5 , angle between the mid-vein and second from the leaf base second-order vein.

\subsection{Soil Contamination Assessment}

In order to assess soil contamination we germinated the Japanese leek Allium fistulosum L. in a thermostat in optimal humidity and moistening conditions. Noticeable root remains were removed from the tested soil with tweezers; a 60 g sample was placed into a Petri dish, brought to thick-paste-like consistency with water, and carefully evened. Fifty seeds of the test object, previously soaked in water for 24 hours, were put on the soil surface. Control seeds were put on moistened cotton wool covered with filter paper. Seeds were germinated for 5-7 days in constant temperature being moistened each day. Soil toxicity level was determined by the difference in the amount of germinated seeds and the length of the germs and roots in trial and control. Mutagenic activity was determined with the method suggested by Blinovsky et al. (1992). For analysis we used germs with roots 1.5-2.0 cm long. Germs were fixed with ethanol and acetic acid in the ratio of 3:1 for 24 hours at $+4^{\circ} \mathrm{C}$. We used anaphase-telophase method with

Amount of changes in chromosome structure was calculated using anaphase-telophase method and squash slides stained with Schiff reagent. We calculated mitosis pathologies (MP), i.e. a proportion of cells with mitosis abnormalities in total amount of anaphase and telophase cells (no less than 400 cells). As the control we used seeds of the Japanese leek germinated using water. More than 20,000 anaphase and telophase cells were analyzed.

Statistical treatment of the results was performed with standard methods. The statistical significance of differences was evaluated using Student's t-test. Correlation was calculated with Pearson's rho (Zaitsev, 1991). 


\section{Results}

\subsection{Assessment of FA Value}

Analysis of FA value of the Japanese White Birch in unimpaired habitats of the Central and West Yakutia showed similar FA levels: in favorable conditions FA value of the Japanese White Birch varies within 0.039-0.044

On the territory of Yakutsk the studies were conducted for five years, the amount of points covered was between 10 and 45. Averaged FA values of the Japanese White Birch for the city territory varied between 0.048 and 0.051 , which may be attributed to both anthropogenic pressure and weather conditions during different years (Table 1).

Table 1. Averaged FA values of the Japanese White Birch on the territory of Yakutsk

\begin{tabular}{cccc}
\hline Year & $\mathrm{n}$ & $\mathrm{M}$ & $\mathrm{m}$ \\
\hline 2000 & 1000 & 0.051 & 0.002 \\
2001 & 1000 & 0.048 & 0.002 \\
2002 & 2500 & 0.049 & 0.002 \\
2003 & 1200 & 0.051 & 0.002 \\
2004 & 4500 & 0.048 & 0.002 \\
2005 & 2300 & 0.048 & 0.002 \\
\hline
\end{tabular}

Note: $n$, sample size; $M$, arithmetic mean; $m$, coverage error.

In V. M. Zakharov view, in the silver birch FA value lower than 0.044 indicates minimal aberrations, and that higher than 0.054 indicates critical state of the organism and extremely unfavorable environmental conditions (Zakharov et al., 2000 b). Our studies produce similar results for the Japanese White Birch (Shadrina et al., 2003; Shadrina et al., 2009; Shadrina et al., 2012 a). Therefore the state of birches in the boundaries of Yakutsk can be characterized as different from that in the wild and unhealthy. In different parts of the city significant spread of FA values was noted (between 0.042 and 0.057 ), and on the basis of the obtained data a map of environmental fitness of the Yakutsk territory was compiled (Soldatova \& Shadrina, 2007)). FA values for points with similar conditions (equal traffic load, illumination) often were similar, so we divided the city territory into three zones: intensive, temperate, and slight anthropogenic impact. Maximal FA values were registered in birches situated along the streets with the heaviest traffic load, in the center of the city, and also along the streets open for truck transport. Average FA values for each zone can be seen in the table 2; it shows that FA value of the Japanese White Birch differs between the zones with a high degree of statistical significance. At the same time, FA value in birches from the zone of slight impact is virtually the same as in the trees from the unimpaired biotopes of the recreation zone.

Table 2. Average FA values of the Japanese White Birch and traffic load in different zones of Yakutsk

\begin{tabular}{cccc}
\hline Zones & $\mathrm{n}$ & $\mathrm{M} \pm \mathrm{m}$ & Vehicles/hour \\
\hline Intensive impact & 600 & $0.052 \pm 0.002$ & 1624 \\
Temperate impact & 600 & $0.048 \pm 0.002$ & 1205 \\
Slight impact & 500 & $0.045 \pm 0.002$ & 624 \\
Recreation zone & 100 & $0.044 \pm 0.003$ & - \\
\hline
\end{tabular}

Besides, FA level was noticed to depend on traffic load, correlation coefficient was 0.85 (Figure 2a), as well as on total content of heavy metals in soil (Figure 2b). Correlation coefficient between FA value and negative factor intensity is approximately 0.78 in the first case, and 0.94 in the second case.

Like other authors, we noted the dependency of aberrations in developmental homeostasis on the proximity of trees to the road surface (Soldatova \& Shadrina, 2007; Soldatova, Shadrina, \& Tsopa, 2009; Konstantinov, 2001). Even in the center of the city, FA value varies depending on the distance from the road as well as on the 
openness of the area (Figure 4). That variability in FA level depends on traffic load was evidenced by the example of an intersection observed for two years. During the first year FA value was 0.055 , which shows critical environment state; the next year one of the streets was blocked due to repair works, the birches were shielded from the roadway by a wooden fence and FA value lowered to 0.045 .

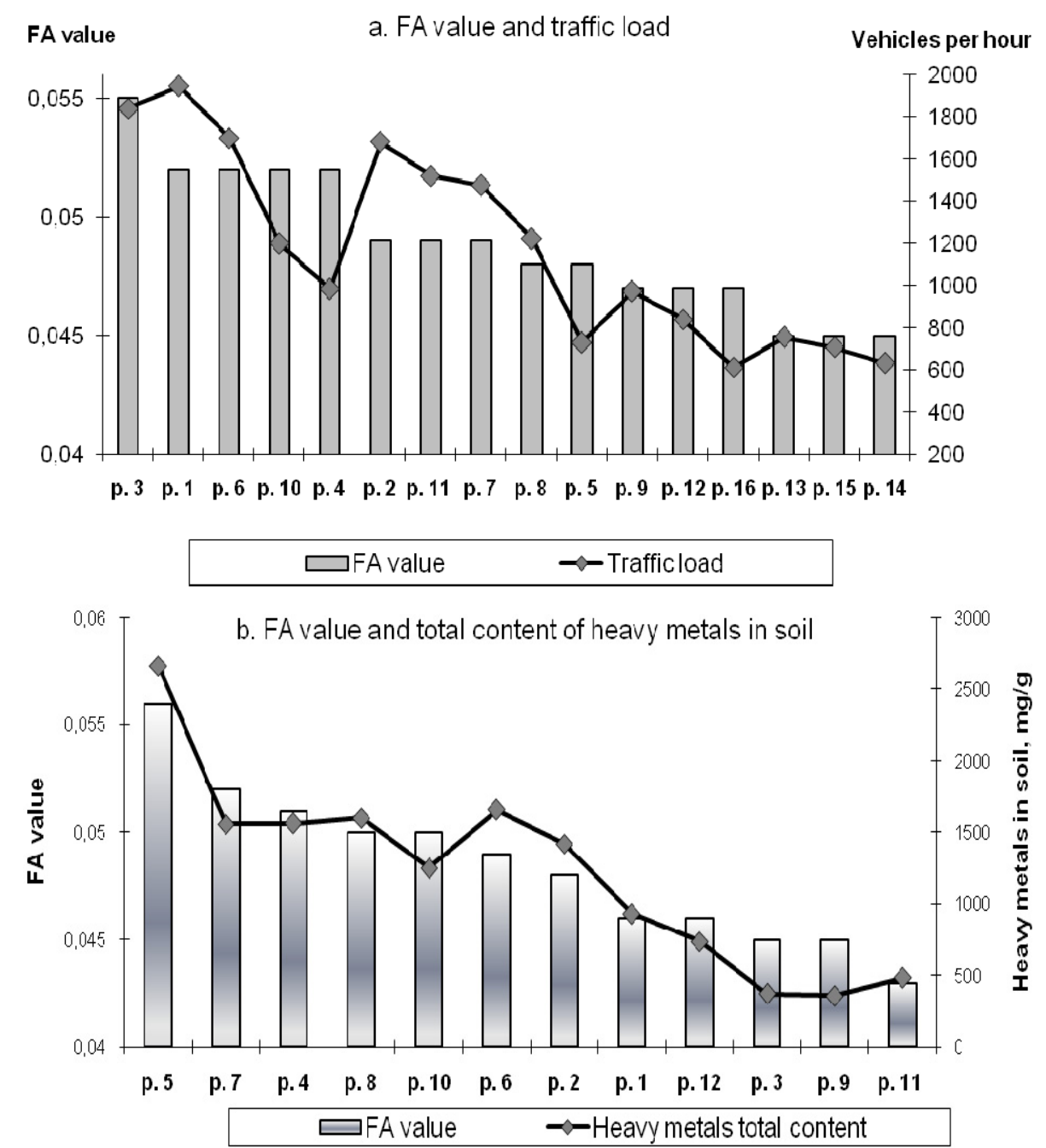

Figure 2. Dependency of FA value on traffic load and total content of heavy metals in soil

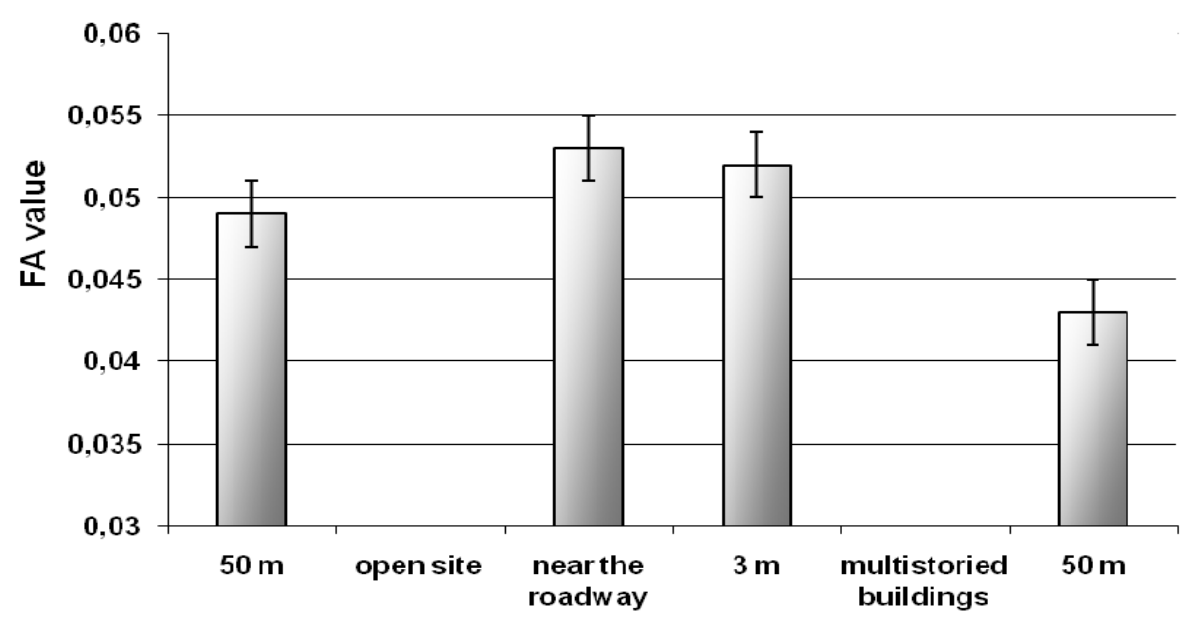

Figure 3. Dependency of FA value of the Japanese White Birch on the proximity to the roadway 
On the whole, the Yakutsk territory is characterized by sharper aberrations in its central area, the zone of maximal traffic load, while on the outskirts and in recreation zone environment state is satisfactory.

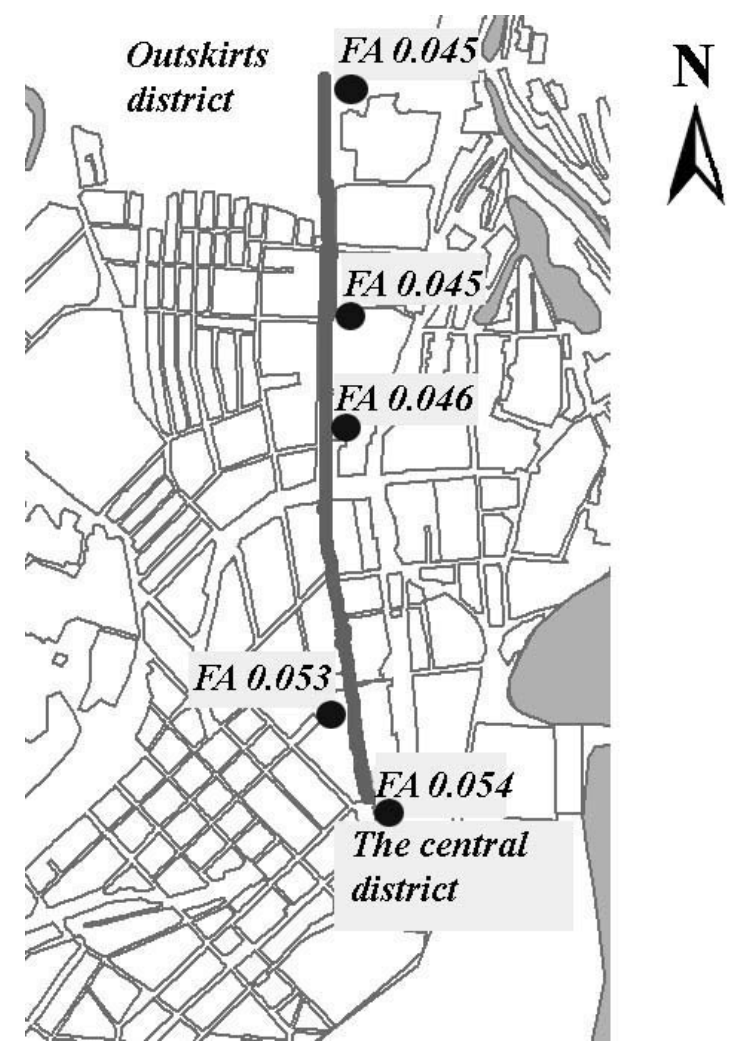

Figure 4. FA values of the Japanese White Birch along one of the main streets of Yakutsk city

The analysis of FA value of the Japanese White Birch on the territory of Mirny and its vicinity also revealed significant differences in integral index value between different points. Value of 0.044 , found in the control point, is indicative of conditions favorable enough, while in biotopes affected by technogenic influence increase in this parameter is observed. The most significant abnormalities in developmental stability were noticed in birches directly affected by chemical and dust impact on the territory of industrial sites, many of them are suppressed, and the value of integral index is $0.048-0.054$. The most pronounced asymmetry is characteristic usually found in leaves of birches along the road on the territory of the open-pit mine, which is significantly higher than on the territory of the control $(\mathrm{p}<0.001)$.

The territory of the city being divided into three zones. The first zone can be described as areas of intensive negative impact; it includes the territory of waste-rock dumps, surroundings of the processing plant, eastern part of the city park, and the area in immediate vicinity of the open pit. FA value there varied within $0.050-0.053$ (Table 3), the difference with the control was characterized by high statistical significance. The second zone can be described as the zone of medium severity impact. It includes the center of the city, where FA value varies within $0.048-0.049$, but can be lower in courtyards. The difference with the control is also reliable, but the significance is lower. The third zone, that of slight impact, is confined to the part of the city farthest from the open pit. There the oldest roadside planting can be found, the traffic load is lower, there are fewer industrial facilities, cottage housing also belongs to this zone. FA value is comparable with that of trees from the control biotopes. For the Mirny territory we compiled a map of environmental quality based on FA levels of the Japanese White Birch (Shadrina et al., 2012 a).

The comparison of birch FA value in 2003 and 2011 showed that general state of the environment of the city territory virtually did not change during this period: generalized data on 14 points afford assessing it as satisfactory (FA 0.049), but taking a look at city districts some changes can be seen - environment state improved for the streets closed for trucks. At the same time it deteriorated in the center and in the older part of the city, which can be explained by the accumulation of pollutants. 
Table 3. FA values of the Japanese White Birch on the territory of Mirny

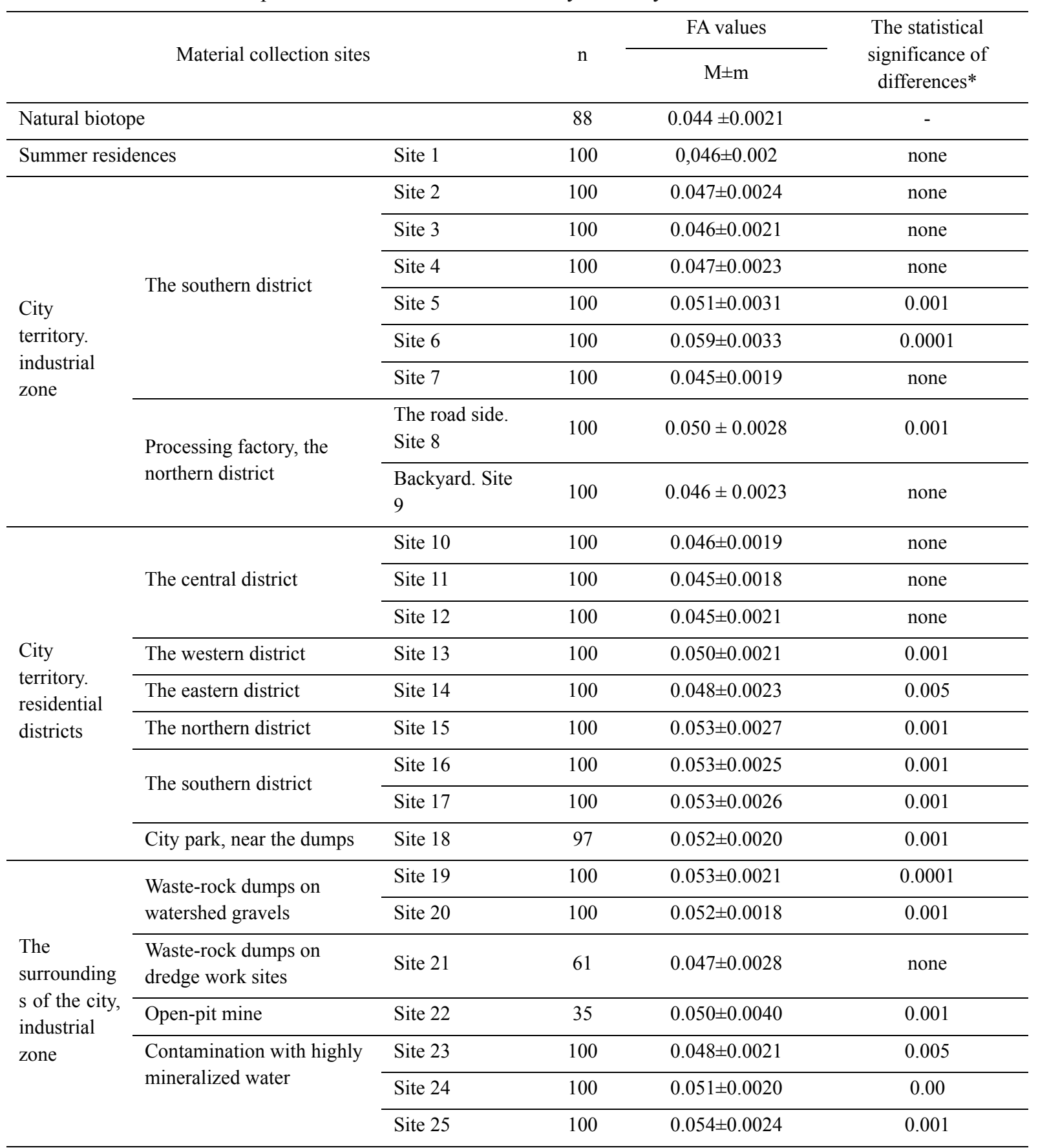

Note: significance of difference using Student's t-test; none, no significant difference.

* The statistical significance of differences between sites under consideration and natural biotope.

\subsection{Soil Contamination Assessment}

On the territory of Yakutsk we collected samples from sites with different levels of traffic load; for the control we used seeds germinated on a sample collected from a biotope subject to very slight anthropogenic load located in the recreation zone of the city, on the territory of the Botanic garden. Mitosis pathologies value in the control point was $6.4 \%$, which is only slightly higher than in seeds germinated using distilled water (Table 4). On the city territory mutagenic activity of soils varied over a wide range, from 4.4 to $18.3 \%$ of the examined anaphase cells. It is worth noting that in a number of points remote from roadways total mutagenic background was as low as or even lower than in the control. 
The most significant increase in MP occurrence was recorded in germs treated with the extract from the samples collected along the streets with the highest traffic load. The maximal level of chromosome abnormalities was registered on crossroads of major streets open for trucks. In these points occurrence of anaphase abnormalities was about $18.2-18.3 \%$, which is significantly higher than in the rest of the city areas (Table 4). In the direction of the outskirts and away from the roadways the proportion of abnormalities lowers. But even in the center of the city low occurrence of chromosome abnormalities can be observed, on out-of-city soils and in the distance from roadways.

Table 4. Occurrence of abnormalities in the Japanese leek germinated on soils from the lawns of Yakutsk

\begin{tabular}{|c|c|c|c|c|c|}
\hline \multirow{2}{*}{ Sample collection sites } & & \multirow{2}{*}{$\begin{array}{c}\text { Anaphase } \\
\text { cells, } \\
\mathrm{n}\end{array}$} & \multirow{2}{*}{$\begin{array}{c}\text { Mitosis } \\
\text { abnormalities, \% } \\
\mathrm{M} \pm \mathrm{m}\end{array}$} & \multicolumn{2}{|c|}{$\begin{array}{c}\text { The statistical significance of } \\
\text { differences, } t, p<\end{array}$} \\
\hline & & & & $\begin{array}{l}\text { With distilled } \\
\text { water }\end{array}$ & $\begin{array}{l}\text { With the control } \\
\text { biotope }\end{array}$ \\
\hline Distilled water & & 836 & $5.4 \pm 0.46$ & - & - \\
\hline $\begin{array}{l}\text { The Botanic garden, recreation } \\
\text { zone. Control }\end{array}$ & Site 1 & 605 & $6.4 \pm 0.13$ & $*$ & - \\
\hline City exit road, northern district & Site 2 & 450 & $6.1 \pm 0.29$ & $*$ & $*$ \\
\hline \multirow{5}{*}{$\begin{array}{l}\text { Central residential districts, near } \\
\text { the buildings }\end{array}$} & Site 3 & 433 & $8.2 \pm 0.34$ & $* *$ & $* *$ \\
\hline & Site 4 & 359 & $7.2 \pm 0.28$ & $* *$ & $* *$ \\
\hline & Site 5 & 205 & $6.3 \pm 0.97$ & $*$ & $*$ \\
\hline & Site 6 & 271 & $4.5 \pm 0.76$ & $*$ & $*$ \\
\hline & Site 7 & 268 & $4.4 \pm 2.17$ & $*$ & $*$ \\
\hline \multirow{2}{*}{ University campus } & Site 8 & 356 & $6.6 \pm 1.10$ & $*$ & $*$ \\
\hline & Site 9 & 519 & $8.7 \pm 0.42$ & $* *$ & $* *$ \\
\hline $\begin{array}{l}\text { The northern industrial district, } \\
\text { near the buildings }\end{array}$ & Site 10 & 471 & $10.7 \pm 0.38$ & $* *$ & $* *$ \\
\hline \multirow{2}{*}{$\begin{array}{l}\text { The northern industrial district, } \\
\text { near the roadway }\end{array}$} & Site 11 & 461 & $12.2 \pm 0.31$ & $* *$ & $* *$ \\
\hline & Site 12 & 456 & $18.2 \pm 0.70$ & $* *$ & $* *$ \\
\hline $\begin{array}{l}\text { The western residential district } \\
\text { near the buildings }\end{array}$ & Site 13 & 441 & $5.5 \pm 0.40$ & $*$ & $* *$ \\
\hline \multirow{3}{*}{$\begin{array}{l}\text { The western residential district } \\
\text { near the roadway }\end{array}$} & Site 14 & 490 & $8.1 \pm 0.30$ & $* *$ & $* *$ \\
\hline & Site 15 & 439 & $13.1 \pm 0.30$ & $* *$ & $* *$ \\
\hline & Site 16 & 479 & $18.3 \pm 0.87$ & $* *$ & $* *$ \\
\hline \multirow{2}{*}{$\begin{array}{l}\text { The Republic } \\
\text { hospital }\end{array}$} & Site 17 & 479 & $10.4 \pm 0.11$ & $* *$ & $* *$ \\
\hline & Site 18 & 553 & $14.2 \pm 0.74$ & $* *$ & $* *$ \\
\hline
\end{tabular}

Note: significance of difference using Student's t-test; * not significant, and ** significant difference.

On the territory of Mirny, occurrence of chromosome abnormalities varied within 7.5-19.4\%, with analysis showing statistically significant increase in chromosome abnormalities level in most samples compared to the control sample (Table 5). The most significant differences are found in points located near the processing plant, motor depot, and in the industrial zone of the city. 
Table 5. Occurrence of chromosome abnormalities in the Japanese leek germinated on lawn soils of the city of Mirny and its industrial sites

\begin{tabular}{|c|c|c|c|c|c|}
\hline Zones & \multicolumn{2}{|c|}{ Sample collection sites } & $\begin{array}{c}\text { Anaphase } \\
\text { cells }\end{array}$ & $\begin{array}{c}\text { Anaphase with } \\
\text { abnormalities, } \%\end{array}$ & $\begin{array}{l}\text { The statistical } \\
\text { significance of }\end{array}$ \\
\hline Control & \multicolumn{2}{|l|}{ Distilled water } & 875 & $5.4 \pm 0.80$ & - \\
\hline \multirow{4}{*}{$\begin{array}{l}\text { City territory, } \\
\text { industrial zone }\end{array}$} & \multicolumn{2}{|c|}{ Motor depot. East district } & 526 & $11.9 \pm 0.33$ & 0.001 \\
\hline & \multirow{2}{*}{$\begin{array}{l}\text { Processing } \\
\text { factory, the } \\
\text { northern district }\end{array}$} & The road side. & 534 & $9.5 \pm 0.28$ & 0.001 \\
\hline & & Backyard & 578 & $9.7 \pm 0.08$ & 0.001 \\
\hline & \multicolumn{2}{|l|}{ The southern district } & 552 & $14.4 \pm 0.27$ & 0.001 \\
\hline \multirow{8}{*}{$\begin{array}{l}\text { City territory, } \\
\text { residential } \\
\text { districts }\end{array}$} & \multirow{2}{*}{ The central district } & Site 1 & 504 & $8.0 \pm 0.29$ & 0.01 \\
\hline & & Site 2 & 562 & $7.5 \pm 0.31$ & none \\
\hline & The eastern district & Site 3 & 497 & $8.1 \pm 0.29$ & 0.01 \\
\hline & The southern district & Site 4 & 547 & $12.7 \pm 0.21$ & 0.001 \\
\hline & The northern district & Site 5 & 469 & $12.2 \pm 0.20$ & 0.001 \\
\hline & The northern district & Site 6 & 415 & $12.1 \pm 0.51$ & 0.001 \\
\hline & The western district & Site 7 & 485 & $11.3 \pm 0.16$ & 0.001 \\
\hline & The western district & Site 8 & 500 & $19.4 \pm 0.84$ & 0.001 \\
\hline \multirow{4}{*}{$\begin{array}{l}\text { The } \\
\text { surroundings of } \\
\text { the city, } \\
\text { industrial zone }\end{array}$} & \multicolumn{2}{|c|}{ Waste-rock dumps on watershed gravels } & 723 & $12.3 \pm 1.20$ & 0.001 \\
\hline & \multicolumn{2}{|c|}{ Waste-rock dumps on dredge work sites } & 1353 & $12.1 \pm 0.90$ & 0.001 \\
\hline & \multicolumn{2}{|c|}{$\begin{array}{l}\text { Contamination with highly mineralized } \\
\text { water }\end{array}$} & 850 & $15.9 \pm 1.21$ & 0.001 \\
\hline & \multicolumn{2}{|c|}{ Shore of a tailings pond } & 1268 & $10.5 \pm 0.92$ & 0.001 \\
\hline
\end{tabular}

Note: t, Student's t-test.

Previously, when we performed an integrated assessment of the environmental quality of the Mirny territory using a wide range of bioindicational and geochemical characteristics, we found that the city environmental quality decreases from the center of the city toward outlying areas (Vol'pert et al., 2005), which is generally unusual for urban territories (Soldatova \& Shadrina, 2007). The analysis of ecological and geochemical data showed that the main way by which pollutants arrives at the territory of the city is through the atmosphere, with motor vehicle emissions not being an essential part of the total pollution. Judging by the composition and distribution character of microelements within residential area, the main contributors into the total pollution level are the territories disturbed by the process of mining for diamonds, that is waste-rock dumps and tailings ponds (Vol'pert et al., 2005).

A circumstantial evidence that the main source of pollution of the city is industrial territories is also the fact that for the samples collected on waste-rock dumps and in sites contaminated with waste waters the total mutagenic background value was in most cases higher than for the samples collected on the territory of the city (Table 5).

When analyzing abnormalities types we noted that in both cities the range of pathologies included all major types of cytogenetic abnormalities: chromosome and chromatid bridges, single-strand and double-strand chromosome fragments, chromosome lagging. The analysis of chromosome abnormalities in soil samples from Mirny showed predominance of such mitosis pathologies as single-strand bridges and fragments, which shows that cells were damaged during $\mathrm{G}_{2}$ stage when chromosomes were duplicated. The lowest and lest variable was the percent of lagging, being (with rare exceptions) almost equally seldom found in samples with different pollution levels and in the control. Mean values of occurrence of fragments and bridges exceeds those in the control sample almost two times. The analysis of the range of chromosome abnormalities on the territory of 
Yakutsk revealed almost equal occurrence of bridges and fragments; both these types, as in the case of Mirny, significantly exceed this of the chromosome lagging.

In most collected soil samples it is also possible to see the dependency between MP level and root growth inhibition. As was noted in literature before, comparative analysis of physiological and cytological effects of toxic metal salts demonstrates a high degree of correlation between their growth inhibiting and cytotoxic effects on germ roots (Dovgalyuk, Kalinyak, \& Blyum, 2001).

\section{Conclusions}

In favorable conditions in unimpaired biotopes FA value of the Japanese White Birch on the territory of Yakutia varies within 0.042-0.044.

In city environment during the period of the study FA value in different points varied between 0.042 and 0.057 . The highest FA value was recorded on streets with heavy traffic load, low levels were recorded in cottage housing area.

The territory of the administrative center, Yakutsk, is characterized by more pronounced abnormalities of developmental stability in its central part, while the state of the outskirts and recreation zone is more satisfactory. FA value within the confines of the city varies in relation to traffic load, and the city territory can be divided into three zone by this parameter: the first zone, with mean FA value of approximately 0.052 (on the average, 1620 vehicles per hour); second, $0.049(1200 \mathrm{~V} / \mathrm{h})$; and third, $0.046(620 \mathrm{~V} / \mathrm{h})$.

Close correlation was noted between FA value of the Japanese White Birch and the proximity of the trees to the roadway and the total level of soil pollution with heavy metal salts.

On the territory of the industrial center, Mirny, more significant abnormalities of developmental stability were recorded in birches suffering from chemical and dust contamination on the territory of industrial sites, while in the center of the city FA value demonstrated moderate abnormalities.

The analysis of total mutagenic background of lawn soils on the territory of the two cities showed that in most samples from residential and commercial areas statistically significant increase in mitosis pathologies can be observed, which indicates presence of pollutants.

In most cases a rise in mutagenic activity is accompanied by root growth inhibition. The most noticeable display of mutagenic effect is occurrence of chromatid bridges and single-thread fragments.

Comparison of mutagenic activity of soils with microelement composition revealed direct dependence of MP occurrence on pollution, with high degree of correlation with lead content.

The pollution of the two cities' territories has different origin. On the territory of the industrial center with low population, that is Mirny, the pollution spreads from technogenically impaired areas to the residential area, which results in the center of the city being less contaminated than the outskirts. On the territory of the administrative center (Yakutsk) the main source of contamination is motor vehicles, which results in major streets, especially in immediate proximity to the roadways, and intersections with heavy traffic load being most contaminated.

All above-mentioned indicates deviations from developmental homeostasis, which manifest themselves in morphological structures of the leaf deviating from bilateral symmetry, as well as in abnormal functioning of mitotic apparatus due to the complex influence of negative factors of anthropogenically transformed environment of the city.

Abnormalities in developmental stability of the Japanese White Birch and mutagenic activity of soils are conspicuous results of various negative factors of anthropogenic nature affecting areas subject to traffic activity, industrial works, and other sources of pollution. This attests to the versatility of these methods and allows one to apply them for assessment of impact of a wide range of factors.

\section{Acknowledgements}

We are grateful to all those who participated in material collection: V.A. Danilov, D.Ya. Shadrin, P.P. Danilov, M.M. Sidorov, and S.I. Poiseeva. Material processing was assisted by students S.V. Petrova, N.N. Alekseeva, and O.V. Grigor'eva. We are also grateful to Ya.B. Legostaeva, N.E. Sivtseva, and L.N. Trofimova for performing chemical analyses and help in interpreting their results. 


\section{References}

Alibert, P., Felclair, F., Manolakou, K., Brittondavidian, J., \& Auffray, J. C. (1997). Developmental Stability, Fitness, and Trait Size in Laboratory Hybrids between European Subspecies of the House Mouse. Evolution, 51, 1284-1295. http://dx.doi.org/10.2307/2411057

Blinovskii, I. K., Khrustaleva, L. I., Zlobin, A. I., Golovina, Yu. M., \& Balakhnina, N. V. (1992). Guidelines for integrated genetic risk assessment of phytohormone use in crop production. Moscow: Kolos.

Danilov, V. A., Shadrina, E. G., \& Vol'pert, Ya. L. (2001). Bioindicational assessment of mining industry impact on biocoenoses of the Aldan River valley. Science and education, 1, 30-34.

Diaz, M., Pulido, F. J., \& Moller, A. P. (2004). Herbivore effects on developmental instability and fecundity of holm oaks. Oecologia, 139(2), 224-234. http://dx.doi.org/10.1007/s00442-004-1491-9

Dovgalyuk, A. I., Kalinyak, T. B., \& Blyum, Ya. B. (2001). Assessment of phyto- and cytotoxic activity of heavy metal compounds. Cytology and genetics, 35(1), 3-9.

Freeman, D. C., Graham, J. H., Byrd, D. W., McArthur, E. D., \& Turner, W. A. (1995). Narrow Hybrid Zone between 2 Subspecies of Big Sagebrush, Artemisia tridentata (Asteraceae). 3. Developmental Instability. American Journal of Botany, 82, 1144-1152. http://dx.doi.org/10.2307/2446068

Gelashvili, D. B., Lobanova, I. V., Erofeeva, E. Ya., \& Naumova, M. M. (2007). Influence of forest-pathology state of the Silver birch on its leaf fluctuating asymmetry level. The Volga region journal of ecology, 6 , 106-115.

Glinyanova, I. Yu., \& Bontar M. M. (2013). Ecological assessment of Volgograd environment as researches of fluctuating asymmetry of leaves of birch white and ordinary lilac. International Scientific Journal for Alternative Energy and Ecology, 11(133), 29-32.

Hodar, J. A. (2002). Leaf fluctuating asymmetry of holm oak in response to drought under contrasting climatic conditions. Journal of Arid Environments, 52, 233-243. http://dx.doi.org/10.1006/jare.2002.0989

Ibragimova, E. E. (2010). Influence of technogenic chemical pollution on size of fluctuating asymmetry of the leaf laminae of Armeniaca vulgaris L. Scientific Notes of Taurida V.I. Vernadsky National University. Ser.: Biology, chemistry, 23(62), 62-67.

Konstantinov, E. L. (2001). Specifics of fluctuating asymmetry of the silver birch lamina as a type of bioindicator (Unpublished doctoral dissertation). Kaluga.

Kozlov, M. V., Wilsey, B. J., Koricheva, J., \& Haukioja, E. (1996) Fluctuating asymmetry of birch leaves increases under pollution impact. Journal of Applied Ecology, 33, 1489-1495.

Kryazheva, N. G., Chistyakova, E. K., \& Zakharov, V. M. (1996). Analysis of developmental stability of the Silver birch under conditions of chemical pollution. Ecology, 6, 441-444.

Kurinnyi, A. I. (1985). Biological indication of pesticide mutagens present in environment using chromosome abnormality occurrence in plants. Cytology and genetics, 19(4), 268-270.

Leary, R. F., \& Allendorf, F. W. (1989). Fluctuating asymmetry as an indicator of stress. Chance use in protect nature. Acta Zool. Fenica, 4, 214-217.

Martel, J., Lempa, K., \& Haukioja, E. (1999). Effect of stress and rapid growth on fluctuating asymmetry and insect damage in birch leaves. OIKOS, 86, 208-216. http://dx.doi.org/10.2307/3546439

Moller, A. P. (1995). Leaf-mining insects and fluctuating asymmetry in elm Ulmus glabra leaves. Journal of Animal Ecology, 64, 697- 707. http://dx.doi.org/10.2307/5849

Parsons, P. A. (1990). Fluctuating asymmetry: an epigenetic measure of stress. Biol. Rev., 65, 131-145. http://dx.doi.org/10.1111/j.1469-185X.1990.tb01186.x

Parsons, P. A. (1992). Fluctuating asymmetry: a biological monitor of environmental and genomic stress. Heredity, 68, 361-364. http://dx.doi.org/10.1038/hdy.1992.51

Savintseva, L. S., Egoshina, T. L., \& Shiryaev, V. V. (2012). Estimation of environmental quality of the city of Kirov using analysis of fluctuating asymmetry of lamina of the silver birch (Betula pendula Roth.). Herald of Udmurt University. Biological Series. Earth Science, 2, 31-37. 
Shabalina, O. M., \& Dem'yanenko, T. N. (2011). Assessment of influence of environment pollution and soil factors on fluctuating asymmetry value of leaves of the silver birch (Betula pendula Roth.) in the city of Krasnoyarsk. Herald of Krasnoyarsk State Agrarian University, 12, 135-140.

Shadrina, E. G. (2004). Bioindication of the impact of mining industry on land ecosystems of the North (Unpublished doctoral dissertation). Yakut State University, Yakutsk, Russia. http://dx.doi.org/10.1134/ S1062360414030059

Shadrina, E. G. (2005). Developmental stability values as a measure of populational variability in small mammals. Populations in space and time. Materials of the 8th All-Russian seminar on populations.

Shadrina, E. G., \& Vol'pert, Ya. L. (2014). Developmental Instability of the Organism as a Result of Pessimization of Environment under Anthropogenic transformation of Natural Landscapes. Russian Journal of Developmental Biology, 45(3), 117-126.

Shadrina, E. G., Pudova, T. M., \& Soldatova, V. Yu. (2012 b). Bioindication of environmental quality during exploration of raw hydrocarbon deposits (by the example of the South-Western Yakutia). Fundamental investigation, 4, 206-211.

Shadrina, E. G., Vol'pert, Ya. L., \& Danilov, V. A. (2009). Values of developmental stability abnormalities in plants and animals as criteria of environmental quality in the area affected by mining industry facilities on the territory of Yakutia. Problems of Regional Ecology, 3, 43-48.

Shadrina, E. G., Vol'pert, Ya. L., Alekseeva, N. N., Danilov, V. A., \& Pudova, T. M. (2012 a). Bioindicational assessment of changes in environmental quality caused by diamond mining facilities. Eurasian Mining, 2, 84-87.

Shadrina, E. G., Vol'pert, Ya. L., Danilov, V. A., \& Shadrin, D. Ya. (2003). Bioindication of mining industry impact on land ecosystems of the North (morphogenetic approach). Novosibirsk: Nauka. Siberian branch, pp: 110.

Sherry, R. A., \& Lord, E. M. (1996). Developmental stability in leaves of Clarkia Tembloriensis (Onagraceae) is related to population outcrossing rates and heterozygosity. Evolution, 50(1), 80-91. http://dx.doi.org/10.2307/2410782

Sherzhukova, L. V., Krivtsova, A. N., Meluzova, M. I., \& Mishalenkova, Yu. N. (2002). Estimation of developmental stability of small-leaved lime on reserved and urbanized territories. Russian Journal of Developmental Biology, 33(1), 11-12. http://dx.doi.org/10.1023/A:1013864810599

Shkil, F. N. (2003). Estimation of the role of conditions of development in a study of geographical variability of morphological traits by the example of a shield bug Graphosoma lineatum L. (Unpublished doctoral dissertation). Institut of developmental biology, Moscow, Russia.

Soldatova, V. Yu., \& Shadrina, E. G. (2007). Fluctuating asymmetry of the Japanese White Birch (Betula platyphylla Sukacz.) as an indicator of environmental quality in a city. Regional Environmental Issues, 5, 70-74.

Soldatova, V. Yu., Shadrina, E. G., \& Tsopa, M. V. (2009). Estimation of environmental quality of the Narofominsk city territory using fluctuating asymmetry value of the silver birch (Betula pendula Roth.). Bulletin of Moscow Society of Naturalists (Biological Series), 114(3), Appx. 1, part 2. Ecology. Natural resources. Rational nature management. Nature conservancy: pp. 365-370.

Vainert, E., Val'ter, R., \& Vettsel', T. (1988). Bioindication of contamination of land ecosystems. Under the editorship of R. Shubert. Moscow: Mir.

Vasil'ev, A. G., Vasil'eva, I. A., \& Marin, Yu. F. (2008). Phenogenetic monitoring of the weeping birch (Betula pendula Roth.) in the Middle Urals: testing a new method for assessing developmental instability in higher plants. Russian Journal of Ecology, 39(7), 483-489. http://dx.doi.org/10.1134/S1067413608070047

Vol'pert, Ya. L., Legostaeva, Ya. B., Shadrina, E. G., Poiseeva, S. I., \& Shchelchkova, M. V. (2005). Integrated assessment of environmental quality on the territory of Mirny city (Yakutia). Basic and applied ecology. Problems of urbanization. Materials of international research-to-practice conference (pp. 78-80). Yekaterinburg.

Wilsey, B. J., Haukioja, E., Koricheva, J., \& Sulkinoja, M. (1998). Leaf fluctuating asymmetry increases with hybridization and elevation in tree-line birches. Ecology, 79(6), 2092-2099. http://dx.doi.org/10.1890/ 0012-9658(1998)079[2092:LFAIWH]2.0.CO;2 
Xu, Z., Hu, T., \& Zhang, Y. (2012). Effects of experimental warming on phenology, growth and gas exchange of treeline birch (Betula utilis) saplings, Eastern Tibetan Plateau, China. European Journal of Forest Research. 131(3), 811-819. http://dx.doi.org/10.1007/s10342-011-0554-9

Youssef, N. A., Gurbanov, E. M., Haciyeva, S. R., Mammedova, A. O., \& Khalilov, R. I. (2013). Antioxidant enzymes, fluctuating asymmetry and morphological changes of urban trees as an ecological indicators of heavy metal stress. International Journal of Pharmaceutical Science and Health Care, 3(1), 1-18. Retrieved from http://www.rspublication.com/ijphc/index.html

Zaitsev, G. N. (1991). Mathematical Analysis of Biological Data (pp. 184). Moscow: Nauka.

Zakharov, V. M. (1987). Asymmetry in Animals. Moscow, Science.

Zakharov, V. M., \& Sikorski, M. D. (1997). Inbreeding and developmental stability in a laboratory strain of the bank vole Clethrionomys glareolus. Acta Theriol, 4, 73-78. http://dx.doi.org/10.4098/AT.arch.97-49

Zakharov, V. M., Baranov, A. S., Borisov, V. I., Valetsky, A. V., \& Kryazheva, N. G. (2000 b). Environmental fitness: methods of estimation. Moscow.

Zakharov, V. M., Chubinishvili, A. T., \& Baranov, A. S. (2001). Environmental fitness: methods and assessment practice in Moscow. Moscow, Center for the environmental policy of Russia.

Zakharov, V. M., Chubinishvili, A. T., Dmitriev, S. G., Baranov, A. S., \& Borisov, V. I. (2000 a). Environmental fitness: estimation practice. Moscow, Center for the environmental policy of Russia: pp. 318.

Zakharov, V. M., Zhdanova, N. P., Kirik, E. F., \& Shkil', F. N. (2001). Ontogenesis and population: evaluation of developmental stability in natural populations. Russian Journal of Developmental Biology, 32(6), 336-351. http://dx.doi.org/10.1023/A:1012825818097

\section{Copyrights}

Copyright for this article is retained by the author(s), with first publication rights granted to the journal.

This is an open-access article distributed under the terms and conditions of the Creative Commons Attribution license (http://creativecommons.org/licenses/by/3.0/). 